\title{
FLAVONOIDS OF Sedum pallescens
}

G. P. Shnyakina and G. G. Z apesochnaya

UDC 547.972

In an ethanolic extract of the epigeal part of Sedum pallescens Freyn. (plume stonecrop), family Crassulaceae, collected in the flowering phase in the Amur region, we have found not less than five substances of flavonoid nature. Two substances were isolated by chromatography on polyamide with elution by a mixture of ethanol and chloroform.

The first substance, $\mathrm{C}_{21} \mathrm{H}_{20} \mathrm{O}_{10}, \mathrm{mp} 231-234^{\circ} \mathrm{C}$ (Kofler), $[\alpha]_{\mathrm{D}}^{20}-140^{\circ}$ (c 0.2 ; methanol), UV spectrum (nm): $\mathrm{MeOH} 254$ (sh.), 267, 324 (sh.), $368(\log \varepsilon 4.27,4.32$ ). On acid hydrolysis it formed rhamnose and an aglycone $\mathrm{C}_{15} \mathrm{H}_{10} \mathrm{O}_{6}$ with $\mathrm{mp} 260-266^{\circ} \mathrm{C}$ identical with kaempferol.

UV and NMR spectroscopy [1] showed that the substance was kaempferol 7-O- $\alpha$-L-rhamnoside.

The second substance, $\mathrm{C}_{27} \mathrm{H}_{30} \mathrm{O}_{14} \cdot{ }^{3} /{ }_{2} \mathrm{H}_{2} \mathrm{O}, \mathrm{mp} 187-189^{\circ} \mathrm{C}$, $[\alpha]_{\mathrm{D}}^{20}-224^{\circ}$ (c 0.55 ; methanol), UV spectrum $(\mathrm{nm}): \mathrm{MeOH} 230$ (sh.), 266, 320 (sh.), 346 ( $\log \varepsilon$ 4.43, 4.26). Acid hydrolysis gave rhamnose and kaempferol with $\mathrm{mp} 266-272^{\circ} \mathrm{C}$. Stepwise hydrolysis in $15 \% \mathrm{CH}_{3} \mathrm{COOH}$ [2] led to the formation of a monoglycoside with $\mathrm{mp} 234-236^{\circ} \mathrm{C},[\alpha]_{\mathrm{D}}^{20}-170^{\circ}$ (c 0.2 ; methanol), identical with the first substance. The NM $\mathrm{R}$ spectrum of the silyl ether had signals of aromatic protons at (ppm) $7.71\left(\mathrm{H}-2^{\prime}, 6^{\prime}\right), 6.82\left(\mathrm{H}^{\prime} 3^{\prime}, 5^{\prime}\right) 6.70(\mathrm{H}-8)$, and $6.18(\mathrm{H}-6)$. The signals of the $\mathrm{CH}_{3}$ groups of the two rhamnose residues are easily distinguished [1]: a doublet at 0.77 ppm with $\mathrm{J}=6 \mathrm{~Hz}$ is given by the methyl group of rhamnose substituted in the 3-OH group of the flavonoid and a complex signal at $1.18 \mathrm{ppm}(3 \mathrm{H})$ by the $\mathrm{CH}_{3}$ of the rhamnose attached at the 7-OH group. Two doublets with $\mathrm{J}=2 \mathrm{~Hz}$ at 5.17 and $5.03 \mathrm{ppm}$ are due to the anomeric protons, and the signals of the other eight protons are located at 2.85-4.28 ppm. The facts presented show that the substance is kaempferol 3,7-di-O- $\alpha-$ L-rhamnoside.

\section{LIT ERATURE CITED}

1. T. J. Mabry, K. R. Markham, and M. B. Thomas, The Systematic Identification of Flavonoids, Springer, New York (1970), p. 269.

2. V. A. Makarov, A. L. Shinkarenko, V. I. Litvinenko, and I. P. Kovalev, Khim. Prirodn. Soedin., 345 (1969).

Khabarovsk State Medical Institute. All-U nion Scient ific-Research Institute of Medicinal Plants. Translated from Khimiya Prirodnykh Soedinenii, No. 4, p. 557, July-August, 1973. Original article submitted February 12, 1973.

(c) 1975 Plenum Publishing Corporation, 227 West 17th Street, New York, N.Y. 10011. No part of this publication may be reproduced, stored in a retrieval system, or transmitted, in any form or by any means, electronic, mechanical, photocopying, microfilming, recording or otherwise, without written permission of the publisher. A copy of this article is available from the publisher for $\$ 15.00$. 